\title{
DEVELOPMENT OF A PERFORMANCE THRESHOLD APPROACH FOR IDENTIFYING THE MANAGEMENT OPTIONS FOR STABILISATION/SOLIDIFICATION OF LEAD POLLUTED SOILS
}

\author{
Pietro Paolo Falciglia ${ }^{a}$, Abir Al-Tabbaa ${ }^{b}$, Federico G. A. Vagliasindi ${ }^{a}$ \\ ${ }^{a}$ Department of Civil and Environmental Engineering, University of Catania, \\ Viale A. Doria, 6-95125 Catania, Italy \\ ${ }^{b}$ Department of Engineering, University of Cambridge, Trumpington Street, Cambridge CB2 1PZ, UK
}

Submitted 13 Dec. 2012; accepted 25 Jun. 2013

\begin{abstract}
Two soils spiked with lead at different rates were stabilised/solidified using Portland cement and fly ash at different soil:binder ratios, and tested for their setting time, unconfined compressive strength, leachability and durability. A performance threshold approach was used in order to identify optimal management options for the products of the S/S treatment. Results show that soil texture, percentage of binders and lead concentration play an important part in the treatment, significantly influencing the performance of the resulting products in terms of curing, compressive strength and durability. $\mathrm{Pb}$ soil concentrations higher than $15000 \mathrm{mg} \mathrm{kg}^{-1}$ were found to heavily reduce the applicability of the treatment requiring the maximum amount of binder in order to satisfy the performance criteria. The performance of sandy soils was shown to be limited by setting time and UCS features due to the retardation of the hydration reactions and also by its leaching behaviour, whereas for silt-clayey soils the critical parameter is the mechanical resistance.
\end{abstract}

Keywords: cement, fly ash, lead $(\mathrm{Pb})$, management options, soil contamination, stabilisation/solidification ( $\mathrm{S} / \mathrm{S})$.

Reference to this paper should be made as follows: Falciglia, P. P.; Al-Tabbaa, A.; Vagliasindi, F. G. A. 2014. Development of a performance threshold approach for identifying the management options for stabilisation/solidification of lead polluted soils, Journal of Environmental Engineering and Landscape Management 22(02): 85-95.

http://dx.doi.org/10.3846/16486897.2013.821070

\section{Introduction}

Lead $(\mathrm{Pb})$-based compounds have been a major source of environmental contamination in the past few decades where lead has been reported to affect human health and it is considered as a possible cause of human cancer (Tang, Yang 2012).

Treatment options for $\mathrm{Pb}$-polluted soils have been reported to be either expensive (soil washing, Torres et al. 2012), require intensive energy consumption (electrokinetic remediation, Ryu et al. 2011), or time consuming, as in the case of biological methods such as bioleaching (Cheng et al. 2009) or phytoremediation (Bech et al. 2012), or environmentally unsustainable, as in the case of disposal in landfills (Harbottle et al. 2007).

Recent studies (Leonard, Stegemann 2010) have also shown the possibility of using stabilization/solidification
(S/S) with hydraulic binders as a possible treatment option, with the potential of using the $S / S$ product for useful purposes. S/S has been widely used due to its versatility, efficiency, time and costs to dispose of low-level radioactive and hazardous wastes, as well as to remedy metal or radionuclides contaminated soils (Falciglia et al. 2012).

Stabilisation/solidification $(S / S)$ is a treatment process by which contaminated soils, sediments or waste materials are mixed with a binder and specific additives with the aims of reducing the mobility of the toxic contaminants by increasing the $\mathrm{pH}$ and fully or partially binding the contaminants in the solid matrix (stabilisation), and of improving the physical properties (strength, compressibility, permeability and durability) of the final treatment products (solidification) (Antemir et al. 2010; Polettini et al. 2001).

\footnotetext{
Corresponding author: Pietro P. Falciglia

E-mail: ppfalci@dica.unict.it
} 
Binder-based stabilisation/solidification (S/S) techniques are used for $\mathrm{Pb}$-polluted soil treatment because they ensure physical and chemical stabilisation by significantly reducing the mobility and the solubility of $\mathrm{Pb}$ in soil (Yin et al. 2006), requiring minimal input of energy, resulting in potential applications in concrete works (AlAnsary, Al-Tabbaa 2007; Harbottle et al. 2007).

For $\mathrm{Pb}$-polluted soil treatment, most applications of $\mathrm{S} / \mathrm{S}$ are cement-based, and rely on Portland cement (PC) as the primary binder (Svensson and Allard 2008). PC is a heterogeneous mixture of five mineral phases: $50-70 \%$ alite $\left(\mathrm{C}_{3} \mathrm{~S}\right), 20-30 \%$ belite $\left(\mathrm{C}_{2} \mathrm{~S}\right), 5-12 \%$ alluminate $\left(\mathrm{C}_{3} \mathrm{~A}\right)$, $5-12 \%$ ferrite $\left(\mathrm{C}_{4} \mathrm{AF}\right)$ and $2 \%$ gypsum. More recently PC has been combined in blends with other minerals such as lime, blast-furnace slag, clays and fly ash. Fly ash (FA), also known as pulverised fuel ash (PFA), is generated from coal fired power plants and, due to its low cost, has been widely used in PC manufacturing and as a partial substitute for $\mathrm{PC}$ as stabilising agent for $\mathrm{Pb}$ in $\mathrm{S} / \mathrm{S}$ treatments. If FA contains more than $20 \% \mathrm{CaO}$, it is classified as self-cementing Class C FA, while Class F FA generally contains less than $10 \% \mathrm{CaO}$. FA presents mechanical features slightly lower than PC (especially Class F), influencing the performance of the S/S treated matrices if used instead of PC as a binder, but it can be successfully used for soil stabilisation or in other civil construction applications (Moon, Dermatas 2007).

The hydration of PC is a sequence of overlapping chemical reactions between dry binder compounds and water, leading to continuous cement paste stiffening and hardening. The early behaviour of hydrating PC is governed by reactions of aluminate phases while the setting and the early strength development behaviour is mostly dependent on the hydration of silicates, particularly alite. The formation of hydration products and the development of micro-structural features depend on solution processes and interfacial and solid-state reactions. The hydration products of PC are mainly made up by $20-25 \% \mathrm{Ca}(\mathrm{OH})_{2}$ (CH), 60-70\% calcium silicate hydrate gel (CSH) and $5-15 \%$ other phases including grains of still-unhydrated cement (Chen et al. 2009).

In particular, using Class F FA, even if it does not readily exhibit self cementing characteristics, upon $\mathrm{PC}$ or lime addition, pozzolanic reactions take place leading to the formation of calcium silicate hydrate gel (CSH) (Dermatas, Meng 2003).

In $\mathrm{Pb}$ polluted soils treated with $\mathrm{PC}$ and/or FA, two possible mechanisms may be responsible for the immobilisation of the contaminant during the hydration phases (Moon, Dermatas 2007). One mechanism may be precipitation resulting from the formation of lead silicate oxide. Another may be inclusion, either by physical encapsulation and or by chemical inclusion. Physical encapsulation can be achieved by creating a solidified monolith, while chemical inclusion can be achieved through the incorporation of lead in binder hydration products, such as CSH gel phases, which play such an important role in the retention of metal. The main mechanisms that determine $\mathrm{Pb}$ immobilization in the solid matrix, similarly to other heavy metals, are: sorption on clay and pozzolanic reaction products (Moon, Dermatas 2007) and addition (Eq. (1)) or substitution (Eq. (2)) reactions with $\mathrm{CSH}$ (Ouki, Hills 2002):

$$
\begin{gathered}
\mathrm{CSH}+\mathrm{Pb} \rightarrow \mathrm{Pb}-\mathrm{CSH} ; \\
\mathrm{CSH}+\mathrm{Pb} \rightarrow \mathrm{Pb}-\mathrm{CSH}+\mathrm{Ca}^{2+} .
\end{gathered}
$$

Several studies on S/S treatment have been performed to better understand the fundamentals of heavy metal immobilisation and leaching (Kundu, Gupta 2008) or to investigate the performance of PC or PC-FA-based S/S treatments of soils polluted by lead. Work carried out by Jing et al. (2004) on leachability of sandy soil contaminated by $\mathrm{Pb}$ at rate of $3800 \mathrm{mg} \mathrm{kg}^{-1}$, treated using $\mathrm{PC}$, lime and lime-FA mixtures, showed that $S / S$ treatments significantly reduced $\mathrm{Pb}$ leaching (below the regulatory concentration) in all performed tests and that $\mathrm{Pb}$ concentration in the leachate is mainly controlled by the leachate $\mathrm{pH}$. Moon and Darmatas (2007) investigated the effectiveness of a FA-based S/S treatment of two soils polluted by $\mathrm{Pb}$ at concentration of 459 and $3530 \mathrm{mg} \mathrm{kg}^{-1}$ by means of semidynamic leaching tests. Results showed a reduction of up to $98.5 \%$ in the $\mathrm{Pb}$ release upon addition of $25 \% \mathrm{FA}$ and that soil contaminant concentration influenced $\mathrm{Pb}$ level in leachate. Moreover, other literature findings (Dermatas, Meng 2003; Qian et al. 2008; Yin et al. 2006) reported that, in a PC and/or FA based treatment, the percentage of binder used, curing age and $\mathrm{Pb}$ contamination level influenced the setting time, compressive strength, leachability and chemical and crystalline structure of the treated soils.

Indeed, it was found that the hydration of cement, and materials such as FA, can be highly modified by heavy metal concentration due to coating around binder grains (Malviya, Chaudhary 2006) and that altered features of hydration products can result in a change of characteristics of the matrices treated by $S / S$ in terms of mechanical strength, durability, curing time, permeability and leachability (Jing et al. 2004; Ouki, Hills 2002). In particular, in the presence of $\mathrm{PC}$ and $\mathrm{FA}, \mathrm{Pb}$, if present at high concentrations, may form, depending on the $\mathrm{pH}$ value, hydroxide and silicate phases characterized by a low solubility such as leadhillite (lead carbonate sulfate hydroxide, $\left.\mathrm{Pb}_{4} \mathrm{SO}_{4}\left(\mathrm{CO}_{3}\right)_{2}(\mathrm{OH})_{2}\right)$, lead carbonate hydroxide hydrate $\left(3 \mathrm{PbCO}_{3} \cdot 2 \mathrm{~Pb}(\mathrm{OH})_{2} \cdot \mathrm{H}_{2} \mathrm{O}\right)$ (Lee 2007) and lead silicate $\left(\mathrm{Pb}_{2} \mathrm{SiO}_{4}, \mathrm{~Pb}_{3} \mathrm{SiO}_{5}\right)$ (Moon, Dermatas 2007) that reduce the permeability of the matrices and increase the setting times.

Therefore, PC and FA based S/S techniques have been documented as appropriate for $\mathrm{Pb}$-contaminated soil 
treatment but the $\mathrm{Pb}$ concentration level has been reported to possibly significantly influence the effectiveness of the treatment. However the correlation between metal contamination level variation and the performance of S/S treated matrices has not been investigated in any detail and in particular, the limits for the application of S/S techniques to treat high $\mathrm{Pb}$ concentration polluted soils are not clear.

Hence, the general objective of this work was to better understand the potential of S/S for the treatment of $\mathrm{Pb}$ polluted soils and in particular the effects of $\mathrm{Pb}$ concentration and soil:binder ratio on the physical and mechanical properties of soil treated with PC and FA which were assessed analysing the setting time, unconfined compressive strength (UCS), leachability and durability of the treatment products.

\section{Materials and methods}

\subsection{Soil, contaminants and binders}

A sandy soil (soil A) and a silty-clay soil (soil B), with properties shown in Table 1, were used for the experiments. Selected soils were spiked with $\mathrm{Pb}$ at different rates (C) (1000, 2000, 4000, 8000, 15000 and $25000 \mathrm{mg} \mathrm{kg}^{-1}$ ), by adding a known quantity of a contaminant solution containing deionized water and reagent grade lead (II) nitrate, purchased from Merck KGaA (Darmstadt, Germany). This nitrate form of $\mathrm{Pb}$ was chosen due to its high solubility, representing a "worst-case" scenario (Jing et al. 2004) and because it is a main pollutant contained in industrial wastes (Gervais, Ouki 2002).

Table 1. Characteristics of the soils

\begin{tabular}{lcc}
\hline \multicolumn{1}{c}{ Parameter } & soil A & soil B \\
\hline Texture & sandy & silty-clay \\
Sand (silica s. $75-350 \mu \mathrm{m}$ ) [\%] & 80 & 20 \\
Silt (silica flour $10-75 \mu \mathrm{m})[\%]$ & 10 & 56 \\
Clay (kaolin $<75 \mu \mathrm{m}$ ) [\%] & 10 & 24 \\
pH (L:S of 10) & 8.73 & 8.39 \\
Organic matter [\%] & 2.79 & 2.98 \\
Total Organic Carbon [\%] & 1.67 & 1.75 \\
Bulk density [g cm ${ }^{-3}$ ] & 1.42 & 1.31 \\
Surface area [m $\mathrm{g} \mathrm{g}^{-1}$ ] & 3.33 & 14.1 \\
Moisture content [\%] & 14 & 25.5 \\
\hline
\end{tabular}

After the contamination procedure, the soils were kept in a closed vessel and stored in a dark room at $4{ }^{\circ} \mathrm{C}$ for 1 month then five samples for each contamination level were collected and analysed for $\mathrm{Pb}$ content before S/S treatments. $\mathrm{Pb}$ content was performed by ICP-OES (Perkin Elmer Optima 4300 with Dual View).

The cement used was purchased as type CEM I Portland cement (PC) CEM 11/B-LL 32.5R from Italcementi
S.p.A. (Italy). Class F fly ash (FA) was obtained from Buzzi Unicem S.p.A. (Italy). The chemical and physical properties of PC and FA are presented in Table 2.

Table 2. Characteristics of the binders

\begin{tabular}{|c|c|c|}
\hline Parameter & PC (type I) & FA \\
\hline \multicolumn{3}{|l|}{ Properties } \\
\hline Moisture content [\%] & 0.1 & 0.4 \\
\hline Bulk density $\left[\mathrm{g} \mathrm{cm}^{-3}\right]$ & 1.2 & 1.5 \\
\hline $\mathrm{pH}(\mathrm{L} / \mathrm{S}$ of 10$)$ & 13.1 & 12.4 \\
\hline Surface area $\left[\mathrm{m}^{2} \mathrm{~g}^{-1}\right]$ & 7.8 & 30.0 \\
\hline \multicolumn{3}{|l|}{ Chemical composition } \\
\hline $\mathrm{SiO}_{2}[\% \mathrm{w} / \mathrm{w}$ dry $]$ & 23.5 & 42.4 \\
\hline $\mathrm{Fe}_{2} \mathrm{O}_{3}[\% \mathrm{w} / \mathrm{w}$ dry $]$ & 3.7 & 2.4 \\
\hline $\mathrm{Al}_{2} \mathrm{O}_{3}[\% \mathrm{w} / \mathrm{w}$ dry $]$ & 4.9 & 37.4 \\
\hline $\mathrm{CaO}[\%$ w/w dry] & 66.3 & 8.3 \\
\hline $\mathrm{MgO}[\% \mathrm{w} / \mathrm{w}$ dry] & 1.6 & 1.9 \\
\hline
\end{tabular}

\subsection{Binder systems and $S / S$ sample production}

The S/S treatment was performed by mixing control or spiked soil (S) samples with a binder mixture (B) of PC and FA (PC:FA 1:1) at three different S:B ratios (3.3:1, 4.0:1, 5.0:1), applied wet using a water (W) to dry binder (DB) ratio of $0.42: 1$ as summarised in Table 3.

Table 3. Details of the soil-binder mixes

\begin{tabular}{ccc}
\hline PC:FA & W:DB & S:B \\
\hline $1: 1$ & $0.42: 1$ & $5.0: 1$ \\
$1: 1$ & $0.42: 1$ & $4.0: 1$ \\
$1: 1$ & $0.42: 1$ & $3.3: 1$ \\
\hline
\end{tabular}

The mixing was performed by means of a food mixer for $15 \mathrm{~min}$ to a homogeneous consistency and the treated soil samples were then cast and compacted into cylindrical moulds (100.0 $\mathrm{mm}$ in height and $50.0 \mathrm{~mm}$ in diameter) in accordance with the ASTM D1557-91 standard. After 1 day, the samples were demoulded then cured for 28 days in sealed sample bags at a temperature of $20 \pm 2{ }^{\circ} \mathrm{C}$ and a relative humidity of $95 \pm 3 \%$ prior to UCS and durability testing.

\subsection{Testing protocol}

To verify the effectiveness of the S/S treatment, it is necessary to assess the characteristics of the treatment products and compare them with specific performance criteria. It is appropriate to establish a testing regime that addresses the relevant issues for the management scenario of the treatment products (e.g. disposal or utilisation) being considered (Perera et al. 2004). The testing protocol on control and soils contaminated at different $\mathrm{C}$ included: (1) setting 
time; (2) UCS; (3) leaching; and (4) wet-dry and freezethaw durability values.

The initial and final setting times of the mixtures were determined by using the ASTM C191-82 method. The setting time of a cementitious mixture is referred to as the period from which water is introduced into the mixture system to the onset of hardening. The initial setting time occurred when the Vicat needle $1.00 \mathrm{~mm}$ in diameter penetrated the mortar mixture to a point of $25 \pm 1 \mathrm{~mm}$, while final setting time occurred when the needle did not visibly sink into the paste.

UCS test relates to the mechanical resistance of the $\mathrm{S} / \mathrm{S}$ products. UCS values were measured according to ASTM test method D1633 by applying a vertical load axially at a constant strain rate of $0.5 \mathrm{MPa} \mathrm{s}^{-1}$ using a Laumas Electronics CTS compressive strength testing apparatus until failure of the cylindrical specimen.

Durability test methods are applied to analyse the long-term performance of the S/S products and in particular the resistance of the material to repeated cycles of weathering. Cured test specimen were subjected to twelve wet/dry (W/D) and freeze/thaw (F/T) cycles according to ASTM D4843 and ASTM D4842 methods, respectively. Specifically, for W/D test each cycle consisted of a period of 5 hours submerged under water and 42 hours in an oven under low-temperature drying condition $\left(71{ }^{\circ} \mathrm{C}\right)$, while for the $\mathrm{F} / \mathrm{T}$ test, each cycle consisted of a 24-hours freezing period at $-20^{\circ} \mathrm{C}$ and a 24 -hours thawing period in water.

$\mathrm{Pb}^{2+}$ leaching behaviour of the products was investigated applying the EN 12457-2 test and the results were compared with E.U. landfill acceptance criteria (Council Decision 2003/33/EC). For the EN 12457-2 test, after the UCS test, coarse particles were separated using a $4.0 \mathrm{~mm}$ sieve. Ninety grams of particle samples were placed into a $1000 \mathrm{~mL}$ polypropylene plastic bottle containing $900 \mathrm{~mL}$ of deionised water ( $\mathrm{pH}$ 6.81) (L:S weight ratio 10:1). The suspension was shaken in a rotary shaker for a period of 24 hours at $10 \mathrm{rpm}$ and $20^{\circ} \mathrm{C}$. After extraction, the final $\mathrm{pH}$ of the leachate was measured and the liquid was separated from the solids by filtration through a $0.45 \mu \mathrm{m}$ glass fibre filter. The filtered leachates were then preserved for $\mathrm{Pb}$ content, which was performed by ICP-OES (Perkin Elmer Optima 4300 with Dual View).

All tests were carried out in triplicate and mean values are shown.

\subsection{Quality criteria}

In preparation for full-scale treatment, and to evaluate the effectiveness of the $S / S$ treatment and the degree to which the $S / S$ objectives were met, some specific quality performance criteria were defined. Performance criteria are also usually developed in conjunction with the objectives of the treatment and the management scenario of the end material (Perera et al. 2004).

The criteria refer to some physical and chemical properties of the S/S solids, measured at 28 days, considering the specific methods adopted for the experiments. The quality criteria were extracted from regulatory limits proposed by US Environmental Protection Agency (US EPA) and United Kingdom Environmental Agency (UK EA) (Stegemann, Cote 1990) and are summarized in Table 4.

Table 4. Quality criteria for S/S materials

\begin{tabular}{|c|c|c|c|}
\hline & & $\begin{array}{l}\text { Range/ } \\
\text { value }\end{array}$ & Regulatory \\
\hline \multicolumn{4}{|l|}{$\begin{array}{l}\text { Physical } \\
\text { properties }\end{array}$} \\
\hline $\begin{array}{l}\text { Setting } \\
\text { time }(\mathrm{h})\end{array}$ & & $5-72$ & $\begin{array}{l}\text { US EPA (Perera et al. } \\
\text { 2004) }\end{array}$ \\
\hline $\begin{array}{l}\text { Initial } \\
\text { setting } \\
\text { time }(\mathrm{h})\end{array}$ & & $2-8$ & $\begin{array}{l}\text { BS EN 196-3:2005 US } \\
\text { EPA (Perera et al. 2004) }\end{array}$ \\
\hline $\begin{array}{l}\text { Final } \\
\text { setting } \\
\text { time (h) }\end{array}$ & & $<24$ & $\begin{array}{l}\text { BS EN 196-3:2005 US } \\
\text { EPA (Perera et al. 2004) }\end{array}$ \\
\hline $\begin{array}{l}\mathrm{UCS} \\
(\mathrm{MPa})\end{array}$ & $\begin{array}{l}\text { Landfill } \\
\text { disposal }\end{array}$ & 0.35 & $\begin{array}{l}\text { USEPA/530-SW-016 US } \\
\text { EPA (Perera et al. 2004) }\end{array}$ \\
\hline $\begin{array}{l}\mathrm{UCS} \\
(\mathrm{MPa})\end{array}$ & $\begin{array}{l}\text { Landfill } \\
\text { disposal }\end{array}$ & 1.00 & BS EN 196-3:2005 \\
\hline $\begin{array}{l}\mathrm{UCS} \\
(\mathrm{MPa})\end{array}$ & $\begin{array}{l}\text { Sanitary } \\
\text { landfill } \\
\text { disposal or } \\
\text { construction } \\
\text { application }\end{array}$ & 3.45 & $\begin{array}{l}\text { USEPA/530-SW-016; } \\
\text { WTC (1991) US EPA } \\
\text { (Perera et al. 2004) }\end{array}$ \\
\hline $\begin{array}{l}\mathrm{UCS} \\
(\mathrm{MPa})\end{array}$ & $\begin{array}{l}\text { Mortar } \\
\text { manu- } \\
\text { facturing }\end{array}$ & 20 & $\begin{array}{l}\text { UK waste disposal } \\
\text { regulatory (Yin et al. } \\
\text { 2006) }\end{array}$ \\
\hline $\begin{array}{l}\text { Weight } \\
\text { loss } \\
\text { after } 12 \\
\text { cycles of } \\
\text { durability } \\
\text { test (\%) }\end{array}$ & & $<30$ & $\begin{array}{l}\text { WTC (1991); US EPA } \\
\text { (Perera et al. 2004), } \\
\text { Stegemann and Cote } \\
(1990)\end{array}$ \\
\hline \multicolumn{4}{|l|}{$\begin{array}{l}\text { Chemical } \\
\text { properties }\end{array}$} \\
\hline $\begin{array}{l}\text { Leachate } \\
\mathrm{Pb} \\
\left(\mathrm{mg} \mathrm{kg}^{-1}\right)\end{array}$ & $\begin{array}{l}\text { Inert waste } \\
\text { landfill } \\
\text { disposal }\end{array}$ & 0.5 & $\begin{array}{l}\text { EU landfill acceptance } \\
\text { criteria (2003/33/EC) } \\
\text { US EPA (Perera et al. } \\
\text { 2004) }\end{array}$ \\
\hline $\begin{array}{l}\text { Leachate } \\
\mathrm{Pb} \\
\left(\mathrm{mg} \mathrm{kg}^{-1}\right)\end{array}$ & $\begin{array}{l}\text { Non } \\
\text { hazardous } \\
\text { waste } \\
\text { landfill } \\
\text { disposal }\end{array}$ & 10 & $\begin{array}{l}\text { EU landfill acceptance } \\
\text { criteria }(2003 / 33 / \text { EC) } \\
\text { US EPA (Perera et al. } \\
\text { 2004) }\end{array}$ \\
\hline $\begin{array}{l}\text { Leachate } \\
\mathrm{Pb} \\
\left(\mathrm{mg} \mathrm{kg}^{-1}\right)\end{array}$ & $\begin{array}{l}\text { Hazardous } \\
\text { waste } \\
\text { landfill } \\
\text { disposal }\end{array}$ & 50 & $\begin{array}{l}\text { EU landfill acceptance } \\
\text { criteria (2003/33/EC) } \\
\text { US EPA (Perera et al. } \\
\text { 2004) }\end{array}$ \\
\hline
\end{tabular}




\section{Results}

\subsection{Testing protocol}

\subsubsection{Setting times}

Figures 1 (a) and 1 (b) show the effects of $\mathrm{Pb}$ soil concentration (C) on the initial and final setting times of the S/S treated soils for a S:B ratio of 3.3:1, 4.0:1 and 5.0:1 and for soils $A$ and $B$, respectively. Results indicate that, especially for soil A, C and S:B ratio significantly influenced the setting times of the $\mathrm{S} / \mathrm{S}$ treated soils. In particular, setting times increased for both soils, with increasing $\mathrm{C}$ and decreased with decreasing the $S: B$ ratio. Higher setting times were observed for soil $\mathrm{A}$, where the presence of $\mathrm{Pb}$ at a $\mathrm{S}: \mathrm{B}$ ratio of 5.0 strongly delayed the hydration reactions and significantly lengthened setting time values (up to $240 \mathrm{~h}$ ) for $\mathrm{C}$ higher than $15000 \mathrm{mg} \mathrm{kg}$. This specific behaviour suggests that when a $\mathrm{Pb}: \mathrm{B}$ threshold ratio is exceeded, a significant increase in the setting time occurs.

These results are consistent with the literature findings where $\mathrm{Pb}$ has been reported to suppress cement hydration and lengthen the setting times due to the precipitation of protective coatings of gelatinous hydroxide around the cement grain surface (Chen et al. 2009). Moreover, results are in agreement with experimental findings obtained by other authors: Gervais and Ouki (2002) found that the initial setting time for a PC system doped with $\mathrm{Pb}$ as nitrate salt at $\mathrm{a} \mathrm{Pb}: \mathrm{B}$ ratio of 0.01 and a $\mathrm{W}: \mathrm{B}$ ratio of 0.45 is delayed to $30 \mathrm{~h}$, whereas, for a PC S/S treated soil with an S:B ratio of 1 , Yin et al. (2006) reported final setting times of $4,8,20$ and $22 \mathrm{~h}$ for a $\mathrm{C}$ of 500,5000 , 25000 and $50000 \mathrm{mg} \mathrm{kg}^{-1}$, respectively.

Considering the less rigorous US EPA acceptance quality criteria of $72 \mathrm{~h}$ for final setting time, inadequate values were obtained for soil $A$ at a $S: B$ ratio of 5.0 for any $\mathrm{Pb}$ contamination level and at a $\mathrm{S}: \mathrm{B}$ ratio of 4.0 only for a $\mathrm{C}$ of $25000 \mathrm{mg} \mathrm{kg}^{-1}$. Adequate values were obtained for soil $\mathrm{B}$ for all the experimental conditions tested. If the BS EN criteria is considered (initial setting time $<8 \mathrm{~h}$, final setting time $<24 \mathrm{~h}$ ), adequate values were obtained only for soil B contaminated at the maximum level of $2000 \mathrm{mg} \mathrm{kg}^{-1}$ for all the $\mathrm{S}: \mathrm{B}$ ratios investigated.

\subsubsection{UCS}

Results of compressive strength (UCS) tested at 28 days of curing for control and treated polluted soils (soil A and B) are presented as a function of $\mathrm{C}$ in Fig. 2.

Results were observed to have an average margin of error of $\pm 7 \%$. Results showed that $\mathrm{C}$ highly influenced UCS and the same trend between UCS and C was observed for both tested soils. Specifically, for all the S:B ratios tested, an increase of UCS was observed for a $\mathrm{C}=$ $1000 \mathrm{mg} \mathrm{kg}^{-1}$ (up to $13000 \mathrm{KPa}$ ) respect to the control samples, followed by a decrease with increasing $\mathrm{C}$ for the highest values. As expected, UCS of the samples increased
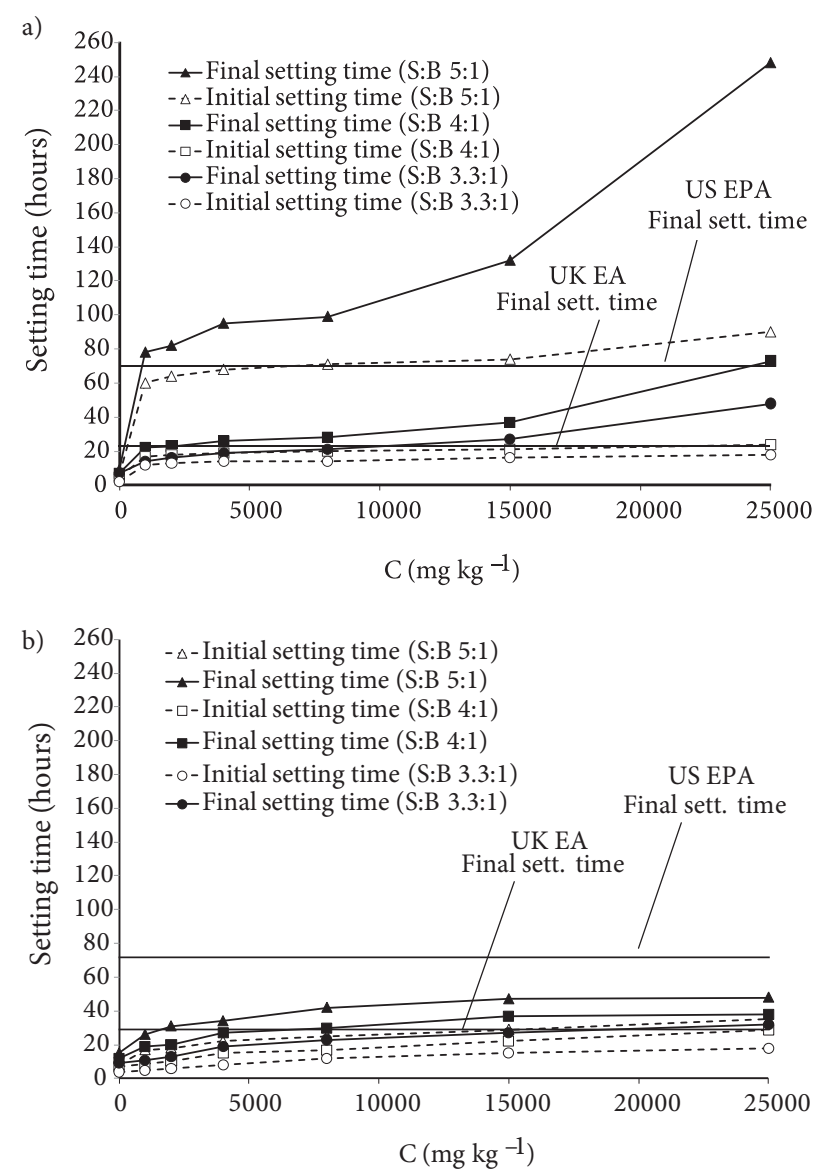

Fig. 1. Setting times of $\mathrm{S} / \mathrm{S}$ treated soils vs $\mathrm{Pb}$ soil concentration for soil A (a) and soil B (b) (S:B ratio of 3.3, 4.0 and 5.0)

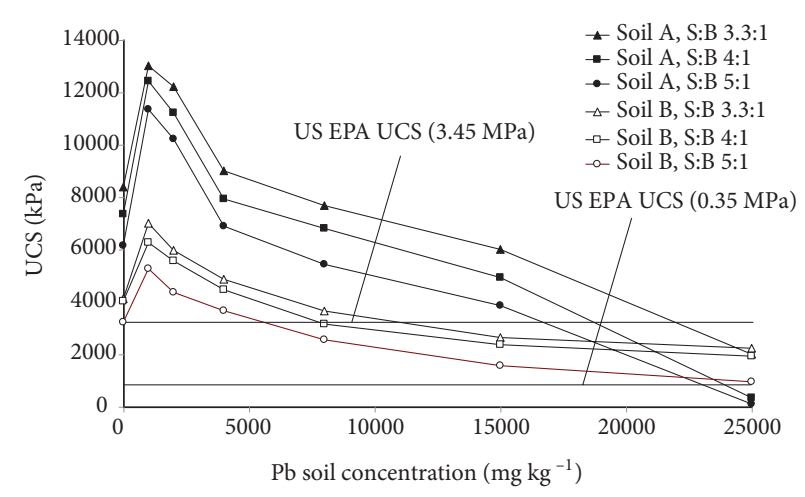

Fig. 2. Effect of $\mathrm{Pb}$ soil concentration on the UCS development of $\mathrm{S} / \mathrm{S}$ soils for soil A and B (S:B ratio of 3.3, 4.0 and 5.0)

with decreasing S:B ratio, and highest values were measured for sandy soil. Overall, excluding the data referred to a $\mathrm{C}=25000 \mathrm{mg} \mathrm{kg}^{-1}$, a difference of between 3000 and $6000 \mathrm{KPa}$ was recorded between UCS of soil A and $\mathrm{B}$ for all the $\mathrm{S}: \mathrm{B}$ ratios. For the samples spiked at a $\mathrm{C}=$ $25000 \mathrm{mg} \mathrm{kg}^{-1}$, a drastic UCS decrease was observed only for the sandy soil. Therefore, it is clear that the presence of low $\mathrm{C}\left(<4000 \mathrm{mg} \mathrm{kg}^{-1}\right)$ results in an improvement of the mechanic characteristics of the $S / S$ treated soils respect to 
the control samples, whereas for higher C, UCS decreased, doing so more rapidly for sandy soil up to values lower than $100 \mathrm{KPa}$.

This specific behaviour is probably due to the lengthening of the hydration reaction that was observed to be more consistent for the sandy soils. As a matter of fact, the better strength performances of the sandy soils are hindered by the higher setting times recorded, especially for high values of $\mathrm{C}$. But, for the lowest $\mathrm{C}$, it seems that the presence of $\mathrm{Pb}$ in the structure of the $\mathrm{S} / \mathrm{S}$ treated soils gave them an improvement in the mechanical features that are not weakened by a significant retardation of the hydration reactions. A previous study (Yin et al. 2006) on S/S treated soils reported an increase of UCS with increasing the $\mathrm{Pb}$ contamination level in soil. Authors observed for a matrix of PC and soil (S:B 2:1) cured at 28 days an UCS of 34, 37 and $47 \mathrm{MPa}$ for a contamination level of 0, 500 and $25000 \mathrm{mg} \mathrm{kg}^{-1}$, respectively. UCS of $34 \mathrm{MPa}$ was also found by Gervais and Ouki (2002) but for a 100\% PC solidified previously doped with $\mathrm{Pb}$ at a $0.01 \mathrm{~Pb}: \mathrm{B}$ ratio.

In terms of quality acceptance, considering the US EPA criteria, insufficient strength values were obtained only for soil A considering a S:B ratio equal to or higher than 4.0 and the maximum $\mathrm{C}\left(25000 \mathrm{mg} \mathrm{kg}^{-1}\right)$ in the cases

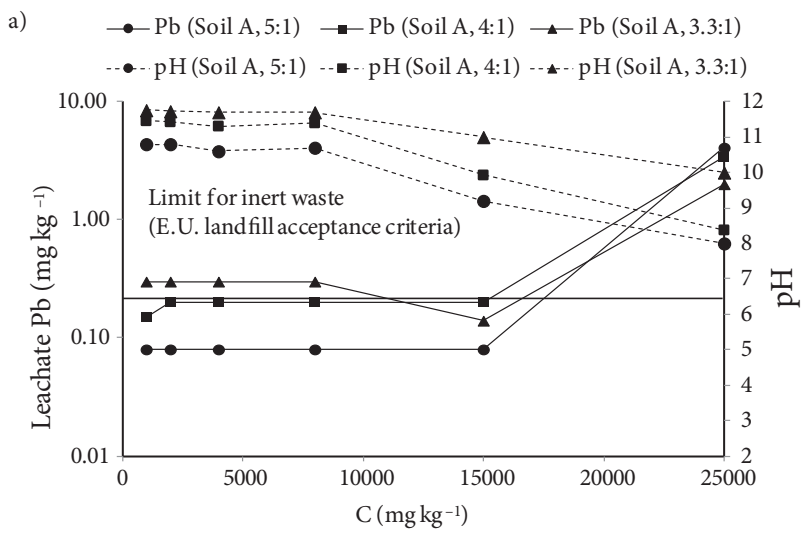

b) $\quad \longrightarrow \mathrm{Pb}$ (Soil B, 5:1) $\neg-\mathrm{Pb}$ (Soil B, 4:1) $\neg-\mathrm{Pb}$ (soil B, 3.3:1)

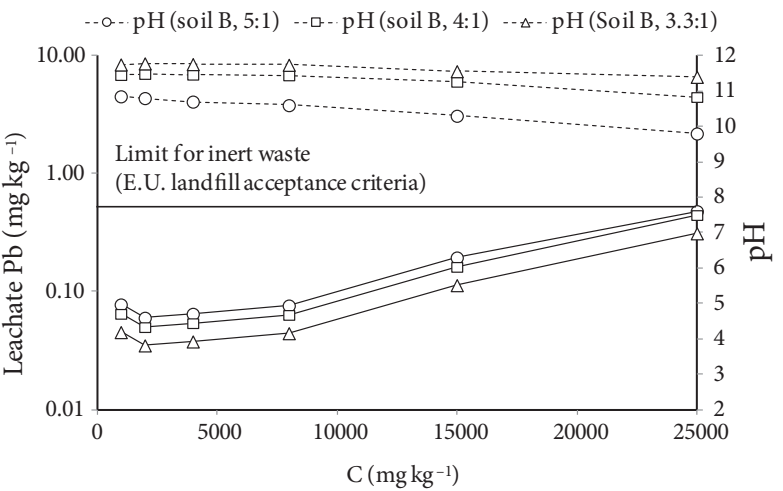

Fig. 3. Effect of $\mathrm{Pb}$ soil concentration on the leachability of lead and $\mathrm{pH}$ of $\mathrm{S} / \mathrm{S}$ treated soils for soil A (a) and soil B (b) $(\mathrm{S}: \mathrm{B}$ ratio of $3.3,4.0$ and 5.0$)$ of S/S treated soils landfill disposal (UCS > $0.35 \mathrm{MPa}$ ). If the more restrictive limit for construction application (UCS > 3.45 MPa) is considered, sufficient UCS values were reached for $\mathrm{C}$ equal to or lower than $15000 \mathrm{mg} \mathrm{kg} \mathrm{kg}^{-1}$ for sandy soil and $4000 \mathrm{mg} \mathrm{kg}^{-1}$ for silty-clay soil. Higher C silty-clay soils (up to $8000 \mathrm{mg} \mathrm{kg}^{-1}$ ) could be successfully treated using a $\mathrm{S}: \mathrm{B}$ ratio of 3.3 or changing the composition of the binder (i.e. increasing the PC content).

\subsubsection{Leachability}

The effect of $\mathrm{C}$ on the $\mathrm{Pb}$ leachability expressed as $\mathrm{mg} \mathrm{kg}^{-1}$ of solid material and on $\mathrm{pH}$ values of leachates resulting from EN 12457-2 test are shown in Fig. 3.

Results were observed to have an average margin of error of $\pm 4 \%$. For all the single batch extractions low values of leached $\mathrm{Pb}$ were observed for $\mathrm{C}$ values up to $8000 \mathrm{mg} \mathrm{kg}{ }^{-1}$, while for higher $\mathrm{C}$ a significant increase was observed in soil A and a slight increase in soil B. This specific behaviour corresponded to $\mathrm{pH}$ values which were above 9.8 for soil B but decreased down to a value of 8.0 for soil $\mathrm{A}$ at the highest $\mathrm{C}$, indicating the higher buffering capacity of the treated samples of soil B compared to those of soil A. As expected, an increase of leached $\mathrm{Pb}$ and a decrease of $\mathrm{pH}$ values were observed with increasing $\mathrm{S}: \mathrm{B}$ ratio. Generally, for most alkaline materials the leaching concentration of $\mathrm{Pb}$ decreases for a $\mathrm{pH}$ reduction from 10 to 8 , but in this case a different trend was observed, probably due to the higher concentration tested that determined an increase in the leaching value even though the reduction in $\mathrm{pH}$ would have yielded a lower concentration.

Furthermore, the theory for which leaching of contaminants such as $\mathrm{Pb}$ is reduced with increasing the percentage of fine texture soil and/or humidity (i.e. soil B) seems to be confirmed. Indeed, an increase of the specific surface area of the S/S matrices and, therefore an increased adsorption of contaminant onto the clay fraction of the soil may produce a decrease in the amount of coating on the cement grains allowing the cement hydration. Moreover, for soil B, the presence of kaolin, that is known to be a good $\mathrm{Pb}^{2+}$ adsorbent (Jiang et al. 2009), especially for high $\mathrm{pH}$ values, improved the adsorption phenomena reducing $\mathrm{Pb}$ leaching. This phenomenon is more relevant for $\mathrm{Pb}$ concentration equal to or higher than $8000 \mathrm{mg} \mathrm{kg}^{-1}$. For both types of soil, the good results obtained, in terms of leachability, are also probably due the presence of a low concentration of organic matter. This condition is in fact known to play an important role in the increase of the immobilization phenomena of $\mathrm{Pb}$ (Janoš et al. 2010).

Comparing the obtained results with E.U. landfill acceptance criteria (Council Decision 2003/33/EC), the leached $\mathrm{Pb}$ for soil $\mathrm{B}$ (all treatments) was below the limit of $0.5 \mathrm{mg} \mathrm{kg}^{-1}$ for inert waste landfill disposal. For soil A, the limit of $0.5 \mathrm{mg} \mathrm{kg}^{-1}$ was respected only for $\mathrm{C}$ equal 
to or lower than $8000 \mathrm{mg} \mathrm{kg}^{-1}$ or for $\mathrm{C}$ equal to or lower than $15000 \mathrm{mg} \mathrm{kg}^{-1}$ using a S:B ratio of 4.0 or 3.3. For the other treatments, leached $\mathrm{Pb}$ was in each case below the limit of $10 \mathrm{mg} \mathrm{kg}^{-1}$ for non-hazardous waste landfill disposal. Results confirm that the main factor controlling the $\mathrm{Pb}$ concentration in the leachate is the final $\mathrm{pH}$, and they are in agreement with those obtained by Jing et al. (2004). This finding on $\mathrm{Pb}$ leachability highlights the possibility of successfully treating also heavy $\mathrm{Pb}$ soil contamination using minimal binder percentage (i.e. $\mathrm{S}: \mathrm{B}=5.0: 1$ ) for siltyclayey soils or using higher binder percentages (depending on the objectives of the treatment) for sandy soils.

\subsubsection{Durability}

For S/S treated soils long-term performance assessment durability tests were performed and results are shown in Figures 4 (a) and 4 (b).

Results were observed to have an average margin of error of $\pm 9 \%$. For the $\mathrm{F} / \mathrm{T}$ test a slight increase of the weight loss was observed with increasing $\mathrm{C}$ for $\mathrm{C} \leq$ $15000 \mathrm{mg} \mathrm{kg}^{-1}$. A significant average variation (about $15 \%$ ) in terms of mass loss was observed between both tested soils. C > $15000 \mathrm{mg} \mathrm{kg}^{-1}$ significantly worsened the performance of the $\mathrm{S} / \mathrm{S}$ matrices, shown by an increase of the mass loss during the durability cycles. Specifically, for the samples where $\mathrm{C}$ was $25000 \mathrm{mg} \mathrm{kg}^{-1}$ a weight loss of 21, 24 and 49\% was achieved respectively for the soil A (S:B 3.3:1), soil B (S:B 3.3:1) and soil B (4.0:1). For the other experimental conditions, all the tested samples were disintegrated after 2 cycles, for soils A (S:B 5.0:1) and B (S:B 5.0:1) and after 8 cycles for soil A (S:B 4.0:1). These results clearly show that, despite the overall best durability performance of the sandy soils, at high $\mathrm{Pb}$ contamination level, they could be more vulnerable than fine texture soils such as soil B. This confirms that in sandy soil, the large retardation of the hydration reactions observed, due to the high $\mathrm{Pb}$ level, may significantly worsen the characteristics of the S/S treated soils and consequently their performance.

For the W/D test a small increase in the weight loss was observed with an increasing of $\mathrm{C}$ for $\mathrm{C}$ equal to or lower than $8000 \mathrm{mg} \mathrm{kg}^{-1}$. For all the samples no difference was observed between $\mathrm{C}=15000$ and $25000 \mathrm{mg} \mathrm{kg}^{-1}$, whereas an increase of about $10 \%$ was observed for soil B in comparison with soil A. The observed decrease in weight loss with an increasing $\mathrm{Pb}$ level in soil may be attributed to the water saturation phenomena regarding the samples during their immersion in water for 5 hours at each cycle of W/D. The presence of a higher amount of water in the sample matrix could play an important role in the improvement of the hydration kinetics that gave the best performance in terms of W/D durability to the treated soils.

Based on the durability acceptance criteria proposed by WTC 1991 and reported by Stegemann and Cote (1990) (weight loss $<30 \%$ ), a minimal S:B ratio is sufficient to
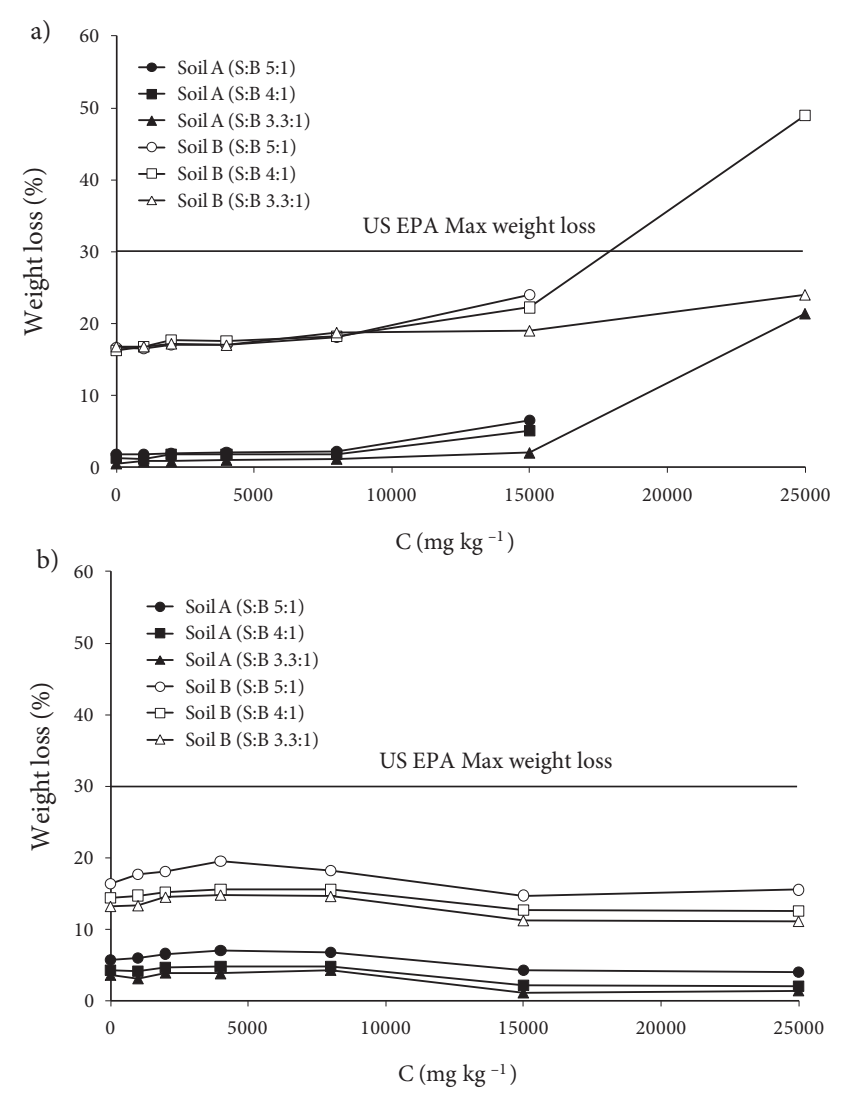

Fig. 4. Effect of $\mathrm{Pb}$ soil concentration on the weight loss of $\mathrm{S} / \mathrm{S}$ treated soils during freeze-thaw (a) and wet-dry (b) durability test for soil A and B (S:B ratio of 3.3, 4.0 and 5.0)

successfully treat a $\mathrm{Pb}$ contamination level equal to or lower than $15000 \mathrm{mg} \mathrm{kg}^{-1}$, whereas a S:B ratio of 3.3 is needed to treat contamination levels up to $25000 \mathrm{mg} \mathrm{kg}^{-1}$.

\subsection{Assessment of $S / S$ management options}

Based on the results obtained by the experimental phase of this work, a performance threshold approach was used to assess potential management options for the S/S treatments. Four management options, namely (1) in situ S/S treatment; (2) hazardous waste landfill disposal; (3) nonhazardous waste landfill disposal; and (4) inert waste landfill disposal or reuse of S/S products for construction materials were chosen for the two investigated soils (sandy and silty-clay soils). Performance thresholds were taken from the performance acceptance criteria reported in $\mathrm{Ta}-$ ble 4 and management options were represented as minimal percentage of binder to use ( $\mathrm{S}: \mathrm{B}$ ratio) versus the $\mathrm{Pb}$ contamination level of the soil (C) for which the selected performance thresholds are all satisfied. The ranges of the values shown on the $\mathrm{x}$ and $\mathrm{y}$ axes represent the limits of the experimental conditions investigated. The $\mathrm{Pb}$ soil concentration limit which can be treated and the related limiting factor and maximum S:B ratio required for sandy and silt-clay soils is reported in Table 5. 
Table 5. Pb soil concentration limit and limiting factor for sandy and silt-clay soils as a function of the scenario adopted

\begin{tabular}{|c|c|c|c|c|}
\hline \multirow[b]{2}{*}{$\begin{array}{c}\text { Scena- } \\
\text { rio - } \\
\text { S:B } \\
\text { ratio }\end{array}$} & \multicolumn{2}{|c|}{ Sand soil } & \multicolumn{2}{|c|}{ Silt-clay soil } \\
\hline & $\begin{array}{l}\mathrm{Pb} \text { concen- } \\
\text { tration limit } \\
\left(\mathrm{mg} \mathrm{kg}^{-1}\right) \\
\text { (S:B ratio } \\
\text { required) }\end{array}$ & $\begin{array}{l}\text { Limiting } \\
\text { factor }\end{array}$ & $\begin{array}{l}\mathrm{Pb} \text { concen- } \\
\text { tration limit } \\
\left(\mathrm{mg} \mathrm{kg}^{-1}\right) \\
(\mathrm{S}: \mathrm{B} \text { ratio } \\
\text { required })\end{array}$ & $\begin{array}{c}\text { Limiting } \\
\text { factor }\end{array}$ \\
\hline 1 & 8000 (3.3) & $\begin{array}{l}\text { Setting } \\
\text { time }\end{array}$ & $4000(4.0)$ & UCS \\
\hline 2 & - & - & - & - \\
\hline 3 & $15000(4.0)$ & UCS & $4000(5.0)$ & UCS \\
\hline 4 & $15000(4.0)$ & $\begin{array}{l}\text { UCS- } \\
\text { Leacha- } \\
\text { bility }\end{array}$ & $4000(5.0)$ & UCS \\
\hline
\end{tabular}

\subsubsection{In situ $S / S$ treatment}

The in situ S/S soil mixing treatment is carried out using mixing augers through which a grout is introduced and mixed with the soil resulting in stabilized/solidified overlapping soil-grout columns (Fleri, Whetstone 2007). Compared to the ex-situ treatments, they could be more hazardous due to the potential risk of a contamination propagation during the realization of the interventions; consequently, high performance acceptance criteria limits were adopted for the purpose.

A fundamental property for the S/S soil-grout columns is the final setting time, since a delay in the $S / S$ mass curing could significantly enhance the leachability of the contaminants. A downward contaminant migration could take place during the in situ mixing processes due to the transitory increase of water amount in soil. For this reason the BS EN limit of $24 \mathrm{~h}$ was adopted. Moreover, to ensure a high mechanical resistance another US EPA restrictive limit of $3.45 \mathrm{MPa}$ was applied for UCS. EU landfill acceptance criteria (2003/33/EC) limit $\left(0.5 \mathrm{mg} \mathrm{kg}^{-1}\right)$ and WTC limit (30\% weight loss) were adopted for leaching and durability tests, respectively. Figures 5 (a) and 5 (b) show the minimal percentage of binder to use ( $\mathrm{S}: \mathrm{B}$ ratio) as a function of $\mathrm{C}$ for which the selected limits are satisfied in the case of an in situ treatment, for a sandy and a silty clay soil, respectively. Results highlight that due to the strict limits adopted, the in situ treatment may be successfully adopted only for not heavy $\mathrm{Pb}$ contamination levels. Specifically, a maximum level of $8000 \mathrm{mg} \mathrm{kg}^{-1}$ and 4000 $\mathrm{mg} \mathrm{kg}^{-1}$ is treatable for a sandy and a silty clay soil, respectively. Moreover, a S:B ratio of 4.0 is adoptable for both the soils up to $2000 \mathrm{mg} \mathrm{kg}^{-1}$, whereas a S:B ratio of 3.3 is necessary for higher contaminations.

\subsubsection{Hazardous waste landfill disposal}

A maximum final setting time of $72 \mathrm{~h}$ and an UCS of $350 \mathrm{kPa}$ at 28 days are suggested by USEPA guidelines for materials that are to be disposed to landfill (Perera et al.
2004) which takes into consideration events such as weight of overburden and land moving equipment. For leaching performance and durability, EU landfill acceptance criteria limit for hazardous waste disposal $\left(50 \mathrm{mg} \mathrm{kg}^{-1}\right)$ and WTC limit (30\% weight loss) were used. Results (Figs 5 (c) and 5 (d)) show that a maximum $\mathrm{C}$ of $15000 \mathrm{mg} \mathrm{kg}^{-1}$ may be treated using a $\mathrm{S}: \mathrm{B}$ of 4.0 and 5.0 for sandy and silty clay soil, respectively, whereas a maximum percentage of binder must be adopted for higher contamination levels. Specifically, for silty clay soil this limitation is due to the durability features, whereas for sandy soil it is due to all the adopted limits except for the leaching limit that is always satisfied. In addition, the worst results, in terms of setting time, were observed for sandy soil, resulting in an $S: B$ values equal to or lower than 4.0 being required for its treatment.

\subsubsection{Non-hazardous waste landfill disposal}

Compared to the previous scenario, a higher UCS value of 3.5 MPa has been suggested by USEPA and WTC (Perera et al. 2004) for disposal to non-hazardous waste (sanitary) landfill because compaction of municipal waste might subject the S/S material to higher stresses because handling, placement and covering operations are not tailored for S/S material. Moreover, the EU landfill acceptance criteria limit for non-hazardous waste disposal $\left(10 \mathrm{mg} \mathrm{kg}^{-1}\right)$ was used. The use of 3.5 MPa limit for UCS results in a strong limitation of the applicability field (Figs 5 (e) and 5 (f)) especially for silty clay soil for which a maximum $\mathrm{C}$ of $4000 \mathrm{mg} \mathrm{kg}^{-1}$ may be treated using a S:B from 3.3 to 5.0 . For sandy soil a higher $\mathrm{C}$ up to $15000 \mathrm{mg} \mathrm{kg}^{-1}$ may be treated but using a S:B from 3.3 to 4.0 .

\subsubsection{Inert waste landfill disposal or reuse for construction}

Compared to the sanitary landfill disposal scenario, a lower limit of $0.5 \mathrm{mg} \mathrm{kg}^{-1}$ for leaching is required by the EU for disposal in inert waste landfill. For both soils, the use of this severe limit for leaching results in the same limitation as the previous scenario (Figs $5(\mathrm{~g})$ and $5(\mathrm{~h})$ ).

\section{Conclusions}

A sandy and a silty-clay soil, spiked with lead at different rates, were S/S treated using a binder mixture of PC and FA (PC:FA 1:1) at different soil:binder ratios, and a testing protocol included setting time, UCS, leaching and durability test were performed to assess the effects of lead and binder level on physical properties of S/S matrices. Based on the experimental results and defining specific quality performance criteria, a performance threshold approach was used to assess potential management options for the S/S treatments. The following conclusions have been drawn according to the results presented above:

1. Soil texture, the percentage of binders used and lead concentration in soil significantly influence 
the performance of the S/S treated soils in terms of curing, compressive and weather cycling strength;

2. The observed influence of lead content on studied parameters may be useful in predicting setting

a)

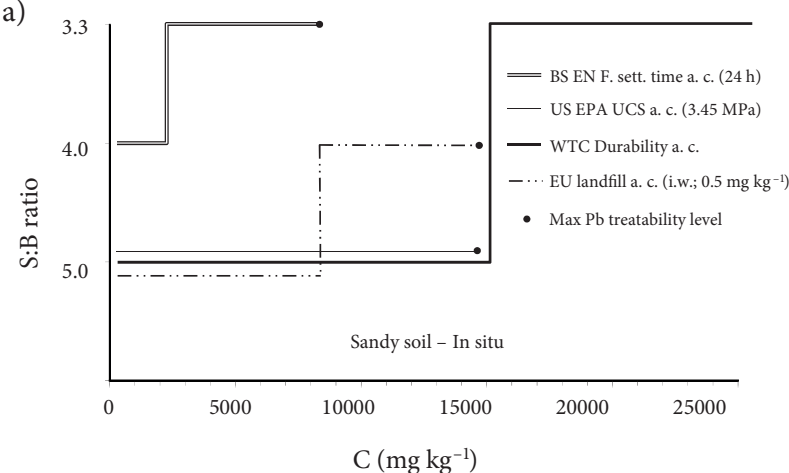

c)

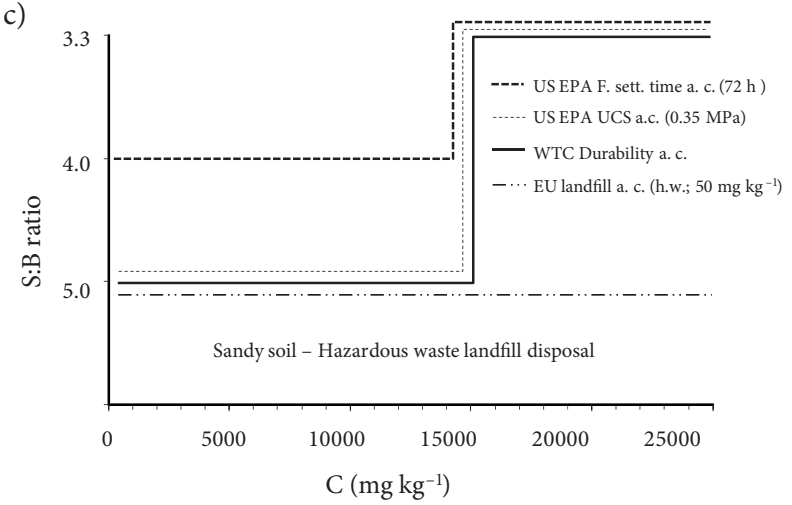

e)

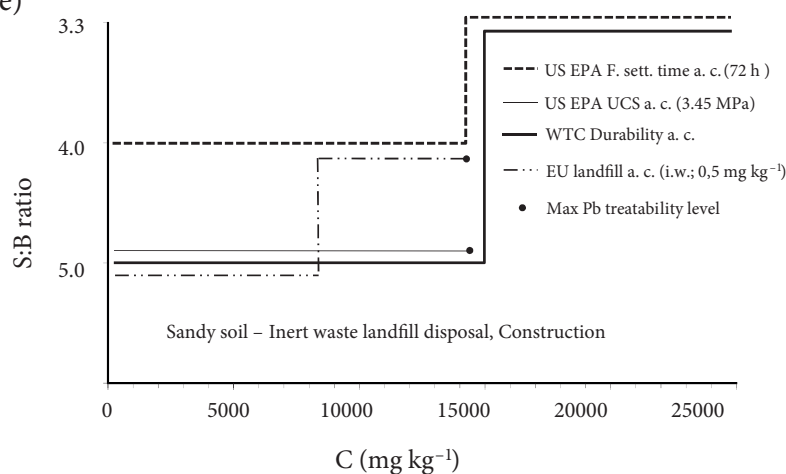

g)

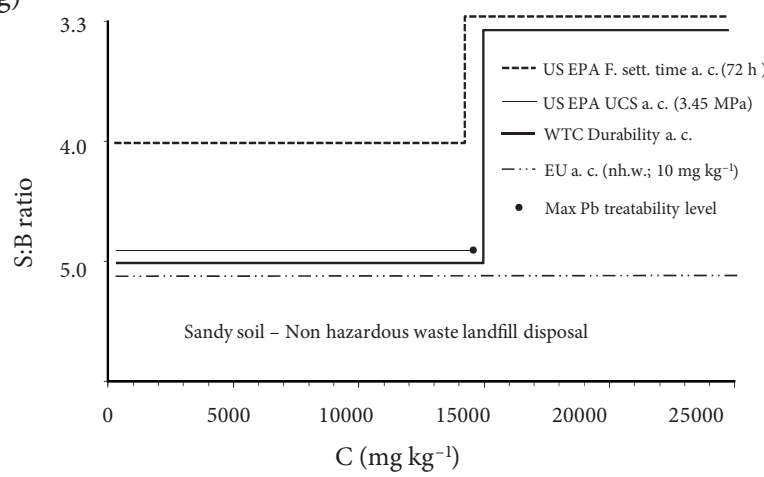

time, UCS, leaching and durability of soils treated by PC and FA at any contamination level;

3. Lead soil concentration higher than $15000 \mathrm{mg} \mathrm{kg}^{-1}$ heavily reduces the applicability of the $\mathrm{S} / \mathrm{S}$ techniques requiring a large amount of binder to satisfy the
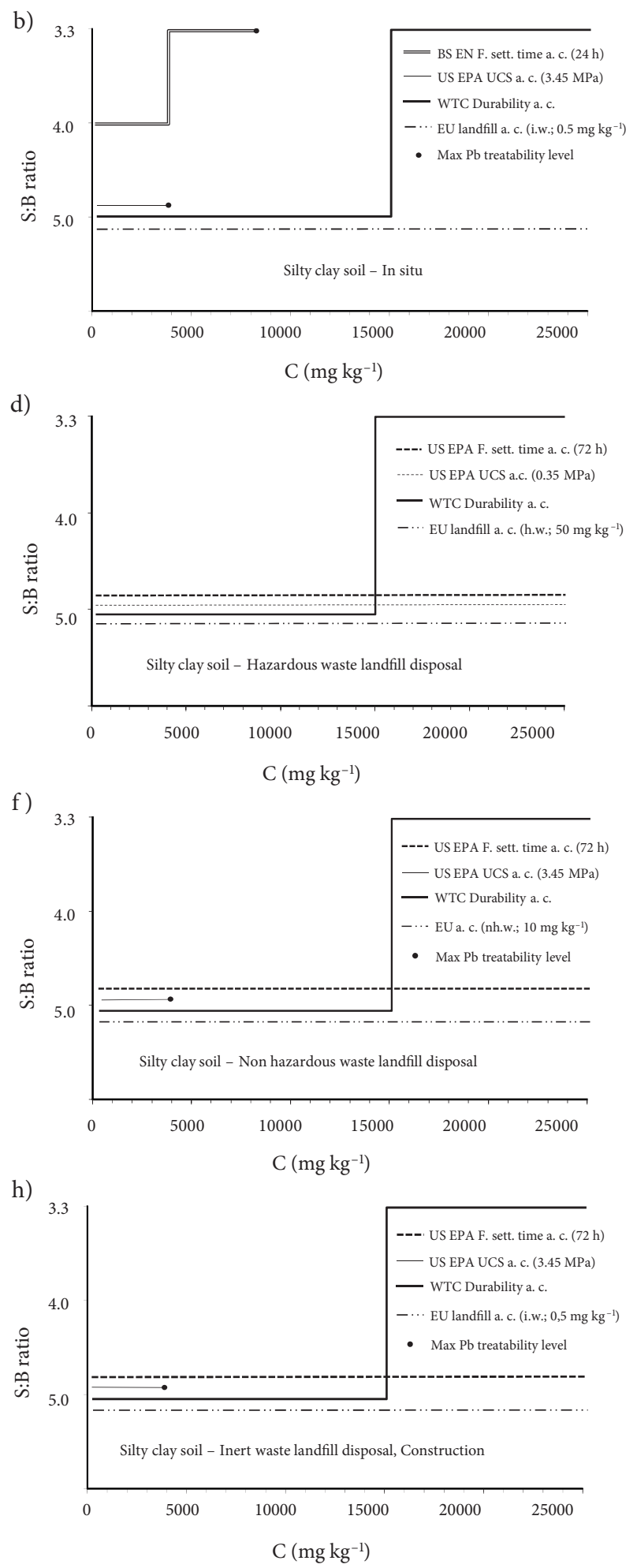

Fig. 5. Percentage of binder to use (S:B ratio) versus $\mathrm{C}$ for which the quality performance criteria thresholds are satisfied for sandy and silty clay soils and different scenarios 
selected performance criteria; this could make the treatment very expensive. Specifically, despite the best compressive strength observed at the lowest lead concentration values, soils performance was shown to be limited by setting time and UCS features due to the lengthening of the hydration reaction;

4. In terms of leachability, lead soil concentration does not represent a limitation, indeed also heavy contamination may be successfully treatable also using minimal binder percentage for any type of soil, except for the in situ and inert waste landfill disposal scenarios, for which, due to the severe limits adopted, a higher soil:binder ratio of 4.0 is required;

5. A strong limitation of the applicability field was observed for an in situ treatment, $S / S$ products reuse or disposal to a landfill, especially for silty clay soils for which only lead concentration lower than $4000 \mathrm{mg} \mathrm{kg}^{-1}$ may be treated in the case of landfill disposal or reuse, while a maximum contamination of $8000 \mathrm{mg} \mathrm{kg}^{-1}$ must be treated using a soil:binder ratio of 3.3:1 in the case of sandy soil in situ treatment;

6. The obtained results are of practical interest and may be used for preliminary cost assessment of full scale remediation activities of lead polluted soils.

\section{References}

Al-Ansary, M. S.; Al-Tabbaa, A. 2007. Stabilisation/solidification of synthetic petroleum drill cuttings, Journal of Hazardous Materials 141(2): 410-421. http://dx.doi.org/10.1016/j.jhazmat.2006.05.079

Antemir, A.; Hills, C. D.; Carey, P. J.; Magnié, M. C.; Polettini, A. 2010. Investigation of 4-year-old stabilised/solidified and accelerated carbonated contaminated soil, Journal of Hazardous Materials 181(1-3): 543-555.

http://dx.doi.org/10.1016/j.jhazmat.2010.05.048

Bech, J.; Duran, P.; Roca, N.; Poma, W.; Sánchez, I.; RocaPérez, L.; Boluda, R.; Barceló, J.; Poschenrieder, C. 2012. Accumulation of $\mathrm{Pb}$ and $\mathrm{Zn}$ in Bidens triplinervia and Senecio $s p$. spontaneous species from mine spoils in Peru and their potential use in phytoremediation, Journal of Geochemical Exploration 123: 109-113.

http://dx.doi.org/10.1016/j.gexplo.2012.06.021

Chen, Q. Y.; Tyrer, M.; Hills, C. D.; Yang, X. M.; Carey, P. 2009. Immobilisation of heavy metal in cement-based solidification/stabilisation: a review, Waste Management 29(1): 390403. http://dx.doi.org/10.1016/j.wasman.2008.01.019

Cheng, Y.; Guo, Z.; Liu, X.; Yin, H.; Qiu, G.; Pan, F.; Liu, H. 2009. The bioleaching feasibility for $\mathrm{Pb} / \mathrm{Zn}$ smelting slag and community characteristics of indigenous moderate-thermophilic bacteria, Bioresource Technology 100(10): 2737-2740. http://dx.doi.org/10.1016/j.biortech.2008.12.038

Dermatas, D.; Meng, X. 2003. Utilization of fly ash for stabilization/solidification of heavy metal contaminated soils, Engineering Geology 70(3-4): 377-394.

http://dx.doi.org/10.1016/S0013-7952(03)00105-4

European Communities Council Decision 2003/33/EC. Establishing criteria and procedures for the acceptance of waste at landfill.

Falciglia, P. P.; Cannata, S.; Romano, S.; Vagliasindi, F. G. A. 2012. Assessment of mechanical resistance, g-radiation shielding and leachate g-radiation of stabilised/solidified radionuclides polluted soils: preliminary results, Chemical Engineering Transactions 28: 127-132.

Fleri, M. A.; Whetstone, G. T. 2007. In situ stabilisation/solidification: project lifecycle, Journal of Hazardous Materials 141(2): 441-456. http://dx.doi.org/10.1016/j.jhazmat.2006.05.096

Gervais, C.; Ouki, S. K. 2002. Performance study of cementitious systems containing zeolite and silica fume: effects of four metal nitrates on the setting time, strength and leaching characteristics, Journal of Hazardous Materials 93(2): 187-200. http://dx.doi.org/10.1016/S0304-3894(02)00005-5

Harbottle, M. J.; Al-Tabbaa, A.; Evans, C. W. 2007. A comparison of the technical sustainability of in situ stabilisation/solidification with disposal to landfill, Journal of Hazardous Materials 141(2): 430-440.

http://dx.doi.org/10.1016/j.jhazmat.2006.05.084

Janoš, P.; Vávrová, J.; Herzogová, L.; Pilařová, V. 2010. Effects of inorganic and organic amendments on the mobility (leachability) of heavy metals in contaminated soil: a sequential extraction study, Geoderma 159(3-4): 335-341. http://dx.doi.org/10.1016/j.geoderma.2010.08.009

Jiang, M.; Wang, Q.; Jin, X.; Chen, Z. 2009. Removal of Pb(II) from aqueous solution using modified and unmodified kaolinite clay, Journal of Hazardous Materials 170(1): 332-339. http://dx.doi.org/10.1016/j.jhazmat.2009.04.092

Jing, C.; Meng, X.; Korfiatis, G. P. 2004. Lead leachability in stabilized/solidified soil samples evaluated with different leaching tests, Journal of Hazardous Materials 114(1-3): 101-110. http://dx.doi.org/10.1016/j.jhazmat.2004.07.017

Kundu, S.; Gupta, A. K. 2008. Immobilization and leaching characteristics of arsenic from cement and/or lime solidified/stabilized spent adsorbent containing arsenic, Journal of Hazardous Materials 153(1-2): 434-443. http://dx.doi.org/10.1016/j.jhazmat.2007.08.073

Lee, D. 2007. Formation of leadhillite and calcium lead silicate hydrate $(\mathrm{C}-\mathrm{Pb}-\mathrm{S}-\mathrm{H})$ in the solidification/stabilization of lead contaminants, Chemosphere 66(9): 1727-1733. http://dx.doi.org/10.1016/j.chemosphere.2006.07.012

Leonard, S. A.; Stegemann, J. A. 2010. Stabilization/solidification of petroleum drill cuttings: leaching studies, Journal of Hazardous Materials 174(1-3): 484-491. http://dx.doi.org/10.1016/j.jhazmat.2009.09.078

Malviya, R.; Chaudhary, R. 2006. Factors affecting hazardous waste solidification/stabilization: a review, Journal of Hazardous Materials 137(1): 267-276.

http://dx.doi.org/10.1016/j.jhazmat.2006.01.065

Moon, D. H.; Dermatas, D. 2007. Arsenic and lead release from fly ash stabilized/solidified soils under modified semi-dynamic leaching conditions, Journal of Hazardous Materials 141(2): 388-394. http://dx.doi.org/10.1016/j.jhazmat.2006.05.085

Ouki, S. K.; Hills, C. D. 2002. Microstructure of Portland cement pastes containing metal nitrate salts, Waste Management 22(2): 147-151. http://dx.doi.org/10.1016/S0956-053X(01)00063-0

Perera, A. S. R.; Al-Tabbaa, A.; Reid, J. M.; Stegemann, J. A. 2004. State of practice reports, UK stabilization/solidification treatment and remediation - testing and performance criteria, in Al-Tabbaa, A.; Stegemann, J. A. (Eds.). Stabilization/Solidifi- 
cation Treatment and Remediation, Advances in S/S for Waste and Contaminated Land. London: A. A. Balkema Publishers.

Polettini, A.; Pomi, R.; Sirini, P.; Testa, F. 2001. Properties of Portland cement - stabilised MSWI fly ashes, Journal of Hazardous Materials 88(1): 123-138. http://dx.doi.org/10.1016/S0304-3894(01)00292-8

Qian, G. R.; Shi, J.; Cao, Y. L.; Xu, Y. F.; Chui, P. C. 2008. Properties of MSW fly ash-calcium sulfoaluminate cement matrix and stabilization/solidification on heavy metals, Journal of Hazardous Materials 152(1): 196-203. http://dx.doi.org/10.1016/j.jhazmat.2007.06.118

Ryu, B. G.; Park, G. Y.; Yang, J. W.; Baek, K. 2011. Electrolyte conditioning for electrokinetic remediation of $\mathrm{As}, \mathrm{Cu}$, and $\mathrm{Pb}$-contaminated soil, Separation and Purification Technology 79(2): 170-176.

http://dx.doi.org/10.1016/j.seppur.2011.02.025

Stegemann, J. A.; Cote, P. L.; 1990. Summary of an investigation of test methods for solidified waste evaluation, Waste Management 10(1): 41-52.

http://dx.doi.org/10.1016/0956-053X(90)90068-V
Svensson, M.; Allard, B. 2008. Leaching of mercury-containing cement monoliths aged for one year, Waste Management 28(3): 597-603. http://dx.doi.org/10.1016/j.wasman.2007.02.031

Tang, X.; Yang, J. 2012. Long-term stability and risk assessment of lead in mill waste treated by soluble phosphate, Science of the Total Environment 438: 299-303. http://dx.doi.org/10.1016/j.scitotenv.2012.08.054

Torres, L. G.; Lopez, R. B.; Beltran, M. 2012. Removal of As, Cd, $\mathrm{Cu}, \mathrm{Ni}, \mathrm{Pb}$, and $\mathrm{Zn}$ from a highly contaminated industrial soil using surfactant enhanced soil washing, Physics and Chemistry of the Earth 37-39: 30-36.

Yin, C. Y.; Mahmud, H. B.; Shaaban, M. G. 2006. Stabilization/ solidification of lead-contaminated soil using cement and rice husk ash, Journal of Hazardous Materials 137(3): 17581764. http://dx.doi.org/10.1016/j.jhazmat.2006.05.013

Pietro Paolo FALCIGLIA. A graduate of University of Catania, Italy, received a Master of Science from Superior School of Catania in 2004, and a PhD in Civil and Environmental Engineering from University of Salerno (Italy) in 2008. Currently he is a Research Associate and Contract Professor of Remediation and Reclamation of Polluted Sites at the Civil and Environmental Engineering Department of the University of Catania. Publications: author/co-author of over 40 scientific papers. Research interests include waste management and treatment, remediation of polluted sites, wastewater treatment.

Abir AL-TABBAA. She graduated from Bristol University in 1983 in Civil Engineering and obtained an MPhil and PhD degrees in Soil Mechanics in 1984 and 1987 respectively from Cambridge University. In 1991 she took up a lectureship at the University of Birmingham and in 1997 returned to Cambridge University as a University Lecturer, now Reader in Geotechnical Engineering. She is a fellow of Sidney Sussex College. She is a Chartered Engineer and a Member of the Institution of Civil Engineers. She was a member of the British Geotechnical Association Executive Committee (2001-2004), a member of the Institution of Civil Engineers Geotechnical Engineering Advisory Panel (2003-2005), Ground Improvement Advisory Panel (2007-2012) and the UK Representative on the International Society of Soil Mechanics and Geotechnical Engineering Technical Committee TC211 on Ground Improvement. She was awarded the Institution of Civil Engineers Reed and Mallik Medal in 2003 for her paper on the five-year soil mixing treatment work at the West Drayton site near Heathrow Airport. Research interests include soil mix technology, field characterisation of soils, waste, waste management and contaminated land, groundwater, seepage and permeability, geomaterials and constitutive models, materials for extreme environments.

Federico G. A. VAGLIASINDI. A graduate of University of Catania, Italy, received a Master of Science from the Civil Engineering Department at Colorado State University, Fort Collins (CO) in 1991, and a Full Professor of Environmental and Sanitary Engineering at University of Catania, Italy, since March 2002. Has participated to research projects financed by the European Commission, the Italian National Research Council, MIUR (PRIN 1999, 2001, 2004, 2006; Project Aquatec PON 2002), AWWARF (American Water Works Association Research Foundation, USA), EPRI (Energy and Power Research Institute, USA). He has consulted several public administrations involved with the ongoing emergency in the solid waste management and contaminated site remediation in Sicily. He is a member of several professional association, has been a component of the Environmental and Sanitary Section of the Italian Great Risks Commission. Since April 2008, he has been a President of the Italian Association of Sanitary and Environmental Engineering Professors. His research interests include water and wastewater treatment and reuse, integrated solid waste management, contaminated site remediation. 